Lamia T Rejab'

BDS, MSc (Assist Lect)

Ihsan N Behnam ${ }^{1}$

BDS, MSc (Assist Lect)

Basima A Abdullah²

$\mathrm{BSc}, \mathrm{MSc}, \mathrm{PhD}$ (Prof)

\section{Microleakage of fluoride containing propolis varnish}

\begin{abstract}
Dental cavity varnishes used to coat the freshly cut tooth structure to reduce microleakage and post-operative hypersensitivity. Dental cavity varnishes are prepared from natural gum or synthetic resin dissolved in a volatile organic solvent.

The aim of this study is preparation of the fluoridated cavity varnish from propolis. Propolis is a natural gum used by bees to seal their honeycombs, it is available, cheep material in Iraq.

The effectiveness of the propolis varnish in reducing the microleakage under amalgam restoration was evaluated by microleakage test by which microleakage tested by penetration of methylene blue dye and examined microscopically.

The data was analyzed statistically with ANOVA and Duncan's Multiple Range Test.

The results of this study showed that the fluoridated propolis varnish has a good quality and it is highly effective in reducing the microleakage under amalgam restoration.
\end{abstract}

Key Words: Dental varnish, propolis, fluoride microleakage.

\author{
1Department of Prosthetic Dentistry \\ College of Dentistry, University of Mosul \\ 2Department of Microbiology \\ College of Science, University of Mosul
}

$$
\begin{aligned}
& \text { الخلاصة } \\
& \text { يستخدم الطـلاء السني عـادة لطـلاء حفرة السـن } \\
& \text { المحضرة لحشوة السن المعدنية لتقليل التسريب وحساسية }
\end{aligned}
$$

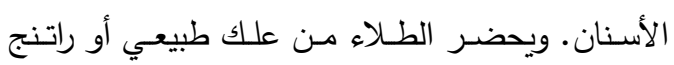

$$
\begin{aligned}
& \text { مصنع يذاب في مذيب عضوي منطاير . }
\end{aligned}
$$

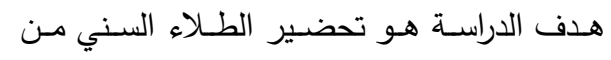

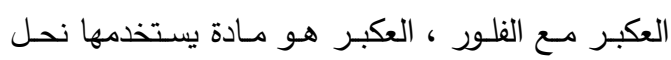

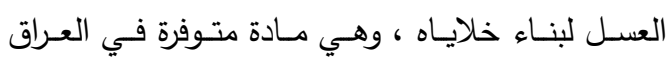

$$
\begin{aligned}
& \text { وبسعر زهيد. } \\
& \text { لقد تم تقييم فعالية الطلاء المصنع من العكبر في }
\end{aligned}
$$

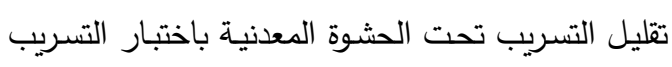

$$
\begin{aligned}
& \text { وذلك باختبـار مدى تسرب صبغة الميثايلين الزرقـاء } \\
& \text { بواسطة الفحص المجهري. } \\
& \text { تم تحليل النتائج إحصائياً واستخراج جدول تحليل } \\
& \text { التباين وفق التصميم العشوائي الكامل واستخدام اختبار }
\end{aligned}
$$

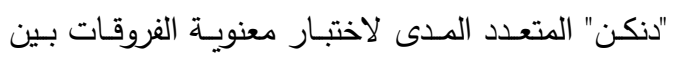

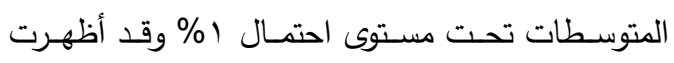

$$
\begin{aligned}
& \text { النتائج أن الطلاء المصنع من العكبر ذو فعالية عالية } \\
& \text { في التقليل من التسريب تحت الحشوة المعدنية. }
\end{aligned}
$$

\section{INTRODUCTION}

The two important disadvantages of amalgam restorations are lack of adhesion to tooth structure and marginal leakage. Marginal leakage can lead to recurrent caries and pulpal injury. Replacement of restorations due to recurrent caries is continuing problem in restorative dentistry. Some restorative materials require liners to decrease microleakage of caries inducing bacteria and acids. Theoretically the continual release of fluoride ions from 
a restorative material could reduce or eliminate recurrent caries. ${ }^{(1,2)}$

Varnishes have been used to minimize leakage around amalgam restorations. Although varnishes may wash out in time, they are replaced by corrosion products of the amalgam. The effectiveness of the liners has been tested in vitro primarily by examining the extent of microleakage of isotops and dyes. ${ }^{(3)}$

High copper spherical alloys have good physical properties in their decreased corrosion but they are inferior to lathe-cut alloys in adaptation to cavity walls, thus, they may be more likely to leak on microscopic level enabling the sealing ability of the lining rather than of the amalgam to be tested. ${ }^{(4,5)}$

Cavity varnishes could be considered as cavity lining agents used for coating freshly cut tooth structure of the prepared cavity. ${ }^{(6,7)}$ The typical varnish is principally a natural gum or synthetic resin dissolved in a volatile organic solvent such as acetone, chloroform or an ether. Varnishes are formulated as fluid substance that readily painted onto the surface of the prepared cavity. The solvent evaporate, leaving a film that protect the underlying tooth structure. ${ }^{(7-10)}$

A cavity varnish will reduce the penetration of fluids around the amalgam and into the dental tubules and reduce post-operative hypersensitivity, but varnishes do not give a thick enough film to provide thermal insulation even if several layers are applied. ${ }^{(6,7)}$

Propolis is a natural gum which is resinous substances sticky, strongly adhesive, collected, transformed and used by bees to seal holes in their honeycombs, smooth out the internal walls and protect the entrance against intruders. ${ }^{(11,12)}$

Propolis is lipophilic, the colour of which varies from yellow-green to dark brown depending on its source and age. In general propolis composed of $50 \%$ resin, $30 \%$ wax, $10 \%$ aromatic oils, $5 \%$ pollen, $5 \%$ various other substance including organic debris. ${ }^{(13,14)}$

Prpolis is reputed to have antiseptic, antimycotic, bacteriostatic, antiinflammatory and anaesthetic properties and there is no contraindication to be used in human. ${ }^{(15-17)}$
With regard to dentistry, propolis inhibit the formation of water-insoluble glucans required by cariogenic Streptococci to adhere to tooth enamel, propolis also increase the microhardness of human enamel and has a significant effect on dentinal hypersensitivity. ${ }^{(18-21)}$

Regarding fluoride, the combined effect of decrease enamel solubility, bacterial enzyme inhibition and enhanced remineralization give fluoride its importance in preventive dentistry. ${ }^{(22,23)}$

Sodium fluoride in $0.05 \%$ solution topically applied is effective in reducing the caries significantly (each $5 \mathrm{ml}$ of $0.05 \%$ sodium fluoride solution contains $1.0 \mathrm{mg}$ of fluoride). Fluoride act by inhibiting the formation of glucans by the cariogenic bacteria Streptococci which aids bacteria to adhere to the tooth structure, also fluoride act against caries by replacing the hydroxyl group of hydroxyapatite crystals $\left(\mathrm{Ca}_{10}\left(\mathrm{PO}_{4}\right)_{6} \mathrm{OH}_{2}\right)$ of enamel by fluoride and form a more acid insoluble fluoroapatite $\left(\mathrm{Ca}_{10}\left(\mathrm{PO}_{4}\right)_{6} \mathrm{~F}_{2}\right)$ and this will lead to increase the enamel microhardness. ${ }^{(24)}$

The aims of the study are preparation of the fluoridated dental cavity varnish from propolis, evaluation of the effectiveness of the propolis varnish in reducing microleakage and compare its effectiveness with other commercially available cavity varnish by microleakage test.

\section{MATERIALS AND METHODS}

\section{Preparation of the Fluoridated Propolis Varnish}

The alcoholic extraction is the usual manner to extract the fraction soluble in alcohol called resin leaving the alcohol insoluble wax fraction. Ninety five percent ethanol was used to extract propolis resin, then the extract was put through series of filters to remove any remaining small particles of foreign materials. ${ }^{(25)}$ Then, the pure extract is dissolved in appropriate amount of an organic solvent which is ether, the amount of mixing based on the characteristic of handling such as flow and ability to be readily seen when applied on 
the surface of the prepared cavity. The varnish should be applied in a thin consistency, if varnish is too viscous it will not wet the cavity well and dose not effectively inhibit marginal leakage, if the varnish become thick upon storage or usage it should be thinned with a solvent. ${ }^{(6,7)}$

Sodium fluoride $(\mathrm{NaF})$ was added to the prepared varnish in concentration $0.05 \%$. $^{(24)}$

\section{Microleakage Test}

Microleakage test was performed to evaluate the effectiveness of the prepared fluoridated propolis varnish in reducing the microleakage under amalgam restoration and compared with commercially available cavity varnish (Copal cavity varnish with fluoride $0.055 \%$ Henry Schein Inc, USA).

Three groups of 10 sound extracted premolar teeth were selected. In each tooth, two opposing class $\mathrm{V}$ were prepared with No. 314 carbide bur in high speed handpiece and water spray coolant. The preparations were box in shape, $2-2.5 \mathrm{~mm}$ in depth.

Group I: Consist of experimental propolis varnish lined restoration on one surface and unlined control restoration on the opposing surface.

Group II: Consist of Copal cavity varnish lined restoration on one surface and unlined control restoration on the opposing surface.

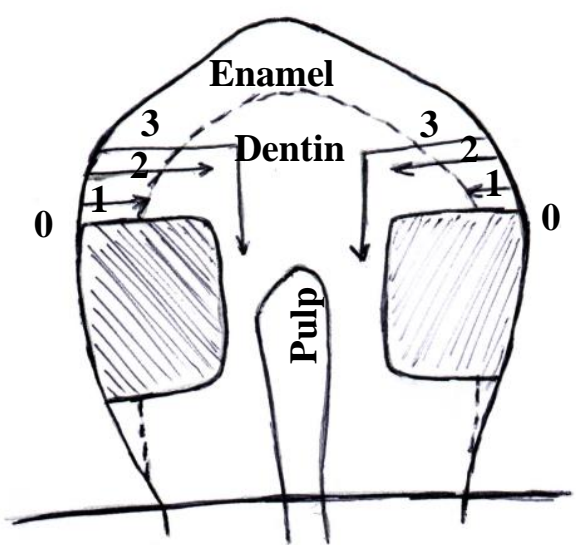

Group III: Consist of experimental propolis varnish lined restoration on one surface and Copal cavity varnish lined restoration on the opposing surface.

For the varnish lined restoration, the cavity preparation were rinsed and dried, coated with two layers of varnish, then the cavity was filled with spherical alloy amalgam (Viva-Cap, Schaan/ Liechtenstein). Amalgam in predose capsule was triturated for 10 seconds in high speed triturator and condensed into the cavity preparation. All restored teeth were stored in water for 24 hours. Next they were exposed to 100 thermal cycle. Each cycle consist of $1 \mathrm{~min}$. each in $6^{\circ} \mathrm{C}$ and $60^{\circ} \mathrm{C}$ water baths and then left over night in a solution with methylene blue dye. After staining all teeth were sectioned through the center of the restoration and evaluated for microleakage with reflected light microscope (Carlzeiss Jena-Germany) at $\times 100$ power. The scoring system for microleakage was shown in Figure (1):

0: No visible penetration of dye.

1: The penetration along the enamel.

2: The penetration along the enamel and dentin but not up to the axial wall of the prepared cavity box.

3: The penetration along the occlusal and gingival wall up to and along axial wall of the prepared cavity box.

The mean values and standard deviation of the leakage score were calculated and the data were analyzed with ANOVA and Duncan's Multiple Range Test at ( $p \leq$ $0.01)$.

Figure (1): Scoring system for microleakage

0: No visible penetration of dye.

1: The penetration along the enamel.

2: The penetration along the enamel and dentin but not up to the axial wall of the prepared cavity box.

3: The penetration along the occlusal and gingival wall up to and along axial wall of the prepared cavity box. 


\section{RESULTS}

The results of the microleakage test are shown in Tables (1) and (2).

Table (1): Means and standard deviation of the microleakage of the tested groups

\begin{tabular}{cccc}
\hline Group & $\begin{array}{c}\text { Number of } \\
\text { Observation }\end{array}$ & Mean \pm SD & $\begin{array}{c}\text { Duncan's } \\
\text { Grouping* }\end{array}$ \\
\hline $\begin{array}{c}\text { Propolis } \\
\text { Varnish }\end{array}$ & 20 & $0.85 \pm 0.745$ & $\mathrm{~A}$ \\
$\begin{array}{c}\text { Copal } \\
\text { Varnish }\end{array}$ & 20 & $1.05 \pm 0.686$ & $\mathrm{~A}$ \\
$\begin{array}{c}\text { Control } \\
\text { Group }\end{array}$ & 20 & $2.25 \pm 0.639$ & $\mathrm{~B}$ \\
\hline
\end{tabular}

Means with same letter have no significant difference. SD: Standard deviation.

Table (2): ANOVA for microleakage mean value of the tested groups

\begin{tabular}{ccccc} 
SOV & df & SS & MS & F-value \\
\hline Group & 2 & 22.9333 & $11.466^{* *}$ & 23.99 \\
Error & 57 & 27.250 & 0.4780 & \\
Total & 59 & 50.1833 & & \\
\hline
\end{tabular}

SOV: Sum of variance; df: Degree of freedom.

SS: Sum of squares; MS: Mean of squares.

$* *$ Means are highly significant different at $p \leq 0.01$

The results in this study showed there is highly significant difference between the varnish lined restorations and unlined control restorations.

The unlined control restorations have the highest mean value (2.25) while the experimental propolis varnish lined restoration have the least value $(0.85)$, but the difference between the propolis varnish lined restoration and Copal varnish lined restoration is statistically not significant.

\section{DISCUSSION AND CONCLUSION}

The results of this study showed that using varnish under amalgam restoration reduce the microleakage significantly and this come in agreement with the finding of Staninec. ${ }^{(4)}$

Also the results appeared that the experimental fluoridated propolis varnish has good quality and effectiveness in reducing the microleakage under amalgam restoration. Although dye penetration is assumed to represent the microleakage that would lead to caries, dye penetration studies have not been proven to predict the susceptibility of the cavity walls to carious attack. ${ }^{(3)}$ The effectiveness of the experimental propolis varnish could be attributed to a combine properties and actions of both propolis extract and fluoride in their anticariogenic effect and increasing the microhardness of the tooth enamel, in that propolis is a lipophilic sticky material, not soluble in water so when it is used with fluoride it has low solubility and act as adherent to prolong the time of the contact of the fluoride with the tooth structure and also serve as fluoride reservoir, and that increase the rate of precipitation of the fluoride within the tooth structure, and then increasing the resistance to acid solubility of the enamel so it reduces the chance to recurrent caries that occur due to microleakage even the varnish might be washed out in time. ${ }^{(24,26)}$

It can be concluded that the fluoridated propolis cavity varnish has an effect in reducing the microleakage under amalgam restoration significantly.

\section{REFERENCES}

1. Staninec M. Bonded amalgam restorations: Laboratory and clinical studies. Cal Printing. San Jose, California, USA. 1999.

2. Suliman AA, Al-Taee MA. Fluoride release from different tooth colored restorative materials: An in vitro study. Al-Rafidain Dent J. 2001; 1(Sp Iss): 215-228.

3. Staninec M, Jow RW, Kirocos LT, Hoover CT. In vitro caries induction at the toothamalgam interface. Dent Mater. 1988; (4): 72-76.

4. Staninec M. Bonding of amalgam to tooth structure: Tensile adhesion and microleakage tests. J Prosthet Dent. 1988; 59: 397-402.

5. Fayyad MA, Ball PC. Cavity sealing lathe cut, blend, and spherical amalgam alloys: A laboratory study. Oper Dent. 1984;9: 86-93. 
6. Skinner EW. Science of Dental Materials. $8^{\text {th }}$ ed. WB Saunders Co. USA. 1987.

7. Anusavice KJ. Philip's Science of Dental Materials. $10^{\text {th }}$ ed. WB Saunders Co. USA. 1996.

8. American Dental Association Specification. Guide to Dental Materials and Device. $7^{\text {th }}$ ed. American Dental Association. USA. 1974-1975.

9. Combe EC. Notes on Dental Materials. $4^{\text {th }}$ ed. Churchill Livingstone. UK. 1981.

10. Glossary of Prosthodontic Terms. J Prosthet Dent. 1994; 71(1): 58.

11. Burdock GA. Review of the biological properties and toxicity of bee propolis. Food Chem Toxicol. 1998; 36: 347-363.

12. Lisowski F. Demystifying health foods. On Contin Prac. 1984; 11: 11-14.

13. Ghisalberti EL. Propolis: A review. Bee World. 1979; 6: 59-84.

14. Munsted K, Zygmunt M. Propolis: Current and future medical UK. Am Bee J. 2001; 141(7): 507-510.

15. Novotny L, Vachalkova A, Al-Nakib T, Mohanna N, Vesela D, Suchy V. Separation of structurally related flavonoids by GC/MS technique and determination of their polarographic parameters and potential carcinogenicity. Neoplasma. 1999; 46: 231-236.

16. Koo H, Comes BP, Rosalen PL. In vitro antimicrobial activity of propolis and arnic montana against oral pathogens. Archs Oral Biol. 2000; 45: 141-148.

17. Marcucci, MC, Ferreres F, Gurcia-Viguera C. Phenolic compounds from Brazilian propolis with pharmacological activities. J Ethnopharmacol. 2001; 74: 105-112.

18. Steinberg, D, Kaine G, Gedalia I. Antibacterial effect of propolis and honey on oral bacteria. Am J Dent. 1996; 9: 549-553.

19. Giamlia I, Steinberg D, Grobler S, Gedalia I. The effect of propolis exposure on microhardness of human enamel in vitro. J Oral Rehabil. 1999; 26: 941-943.

20. Mahmoud AS, Almas K, Dahlan AA. The effect of propolis on dentinal hypersensitivity and level of satisfaction among patients from a university hospital Riyadh, Saudi Arabia. Indian J Dent Res. 1999; 10: 130-137.

21. Abdul-Rahman GhY. Antimicrobial effect of propolis on Streptococcus mutans. AlRafidain Dent J. 2002; 2(Sp Iss): 299-303.

22. McCabe JF. Anderson's Applied Dental Materials. $6^{\text {th }}$ ed. Blackwell Scientific Pub. UK. 1985.

23. Khamarco TY, Jazrawi KH. Topical fluoride gel applications: When and to whom starts therapy? Al-Rafidain Dent J. 2002; 2(1): 32-42.

24. Holroyed SV, Wyun RL. Clinical Pharmacology in Dental Practice. $3^{\text {rd }}$ ed. CV Mosby Co. London. UK. 1983.

25. Marcucci MC. Propolis: Chemical composition, biological properties and therapeutic activity. Apidologie. 1995; 26: 83-99

26. Hart H. Organic Chemistry. $7^{\text {th }}$ ed. Houguton Mifflin Co. USA. 1987. 